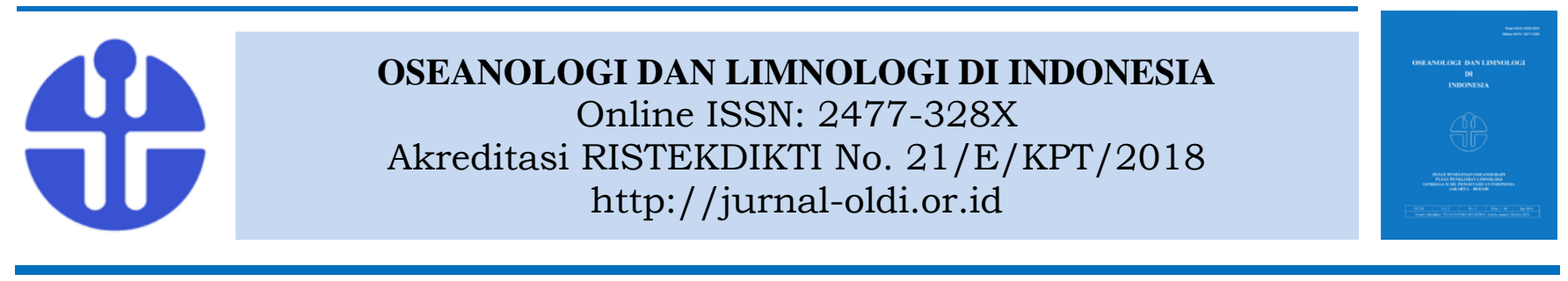

\title{
Struktur Komunitas dan Preferensi Habitat Ikan Karang pada Terumbu Buatan di Teluk Awang dan Teluk Bumbang, Pulau Lombok
}

\author{
Ria Faizah $^{1}$, Lilis Sadiyah ${ }^{1}$ dan Aisyah ${ }^{1}$ \\ ${ }^{1}$ Pusat Riset Perikanan, Badan Riset dan Sumber Daya Manusia Kelautan dan Perikanan, KKP, Jl. Medan \\ Merdeka Timur No. 16, Gambir, Jakarta Pusat, DKI Jakarta \\ Email: faizah.ria@gmail.com
}

Submitted 12 April 2018. Reviewed 5 April 2019. Accepted 4 July 2020.

DOI: 10.14203/oldi.2020.v5i1.202

\begin{abstract}
Abstrak
Teluk Awang dan Teluk Bumbang merupakan lokasi penempatan terumbu buatan untuk pemulihan habitat sumberdaya ikan. Penelitian ini bertujuan untuk mengevaluasi perkembangan setelah penempatan terumbu buatan di kedua lokasi tersebut. Kegiatan dilaksanakan pada bulan Juni dan Desember 2015. Parameter yang diamati meliputi komunitas ikan dan komunitas bentik, parameter biologi (fitoplankton, zooplankton, meroplanton), parameter fisik (suhu, salinitas, konduktivitas, pH, kekeruhan, oksigen terlarut/DO) serta parameter kimia perairan (nitrat dan fosfat). Pengamatan komunitas ikan menggunakan peralatan selam SCUBA, underwater sheet, alat tulis dan GPS, kemudian dilakukan pengamatan secara visual menggunakan modifikasi teknik Stationary Visual Census. Pengamatan komunitas bentik menggunakan peralatan yang sama dengan komunitas ikan dan didata secara visual di lokasi terumbu buatan. Pengukuran parameter fisik dilakukan secara in situ pada permukaan dan dasar perairan (kedalaman 9 dan 11 m) menggunakan alat Water Quality Checker. Parameter biologi diambil menggunakan jaring plankton berukuran $60 \mu, 300 \mu$ dan bonggo ukuran $700 \mu$. Pengambilan sampel air untuk unsur hara dilakukan secara in situ dan dianalisis di laboratorium. Komunitas bentik dikategorikan ke dalam empat bentuk kehidupan (life form), yaitu tutupan karang hidup, karang mati, biota (alga dan biota lain) serta komponen abiotik. Preferensi habitat diidentifikasi melalui analisis komponen utama terhadap faktor yang berhubungan dengan kelimpahan ikan. Hasil penelitian menunjukkan bahwa di lingkungan terumbu buatan dijumpai sebanyak 8 16 spesies ikan karang dari 15 famili, yang didominasi Famili Apogonidae (Archamia fucata), Pomacentridae (Neopomacentrus cyanomos) dan Phempherididae (Phempheris oulensis), dengan kisaran kelimpahan 268 - 1028 ekor. Indeks ekologi menunjukkan tingkat keanekaragaman rendah hingga sedang, indeks dominansi tidak menunjukkan adanya dominansi spesies tertentu serta indeks kemerataan menunjukkan pola penyebaran ikan tergolong rata. Preferensi habitat ikan di Teluk Awang didukung oleh keberadaan alga dan biota lainnya, unsur hara dan salinitas. Sementara di Teluk Bumbang didukung oleh kelimpahan fito-zooplankton, oksigen terlarut, dan turbiditas.
\end{abstract}

Kata kunci: Struktur komunitas, ikan karang, terumbu buatan, Teluk Awang, Teluk Bumbang, preferensi habitat.

\begin{abstract}
Community Structure and Habitat of Coral Fish on Artificial Reef in Awang and Bumbang Bay, Lombok Island. Artificial reefs which were placed in Teluk Awang and Teluk Bumbang intended to restore habitat fish resources. This paper aims to evaluate the development of artificial reefs in both locations. The activities was conducted in June and December 2015. Data collection included fish and
\end{abstract}


benthic communities, biological parameters (phytoplankton, zooplankton, meroplanton), physical parameters (temperature, salinity, conductivity, $\mathrm{pH}$, turbidity, dissolved oxygen), and chemical parameters waters (nitrates and phosphates). Observation of fish community using SCUBA diving equipment, underwater sheets, stationery and GPS, then visual observations using a modified stationary visual census technique. Visual recorded also used for benthic communities. Water sampling taken on the surface and bottom at depths of $9 \mathrm{~m}$ and $11 \mathrm{~m}$ using water quality checker. Biological parameters were taken using $60 \mu, 300 \mu$ and plankton net sizes $700 \mu$. Nutrients were observed in the laboratory by taking water samples in situ. Laboratory tests were carried out for nutrients as well as plankton and meroplankton. Benthic communities were categorized into four life forms, namely live coral covered, dead coral, biota (algae and other biota) as well as the abiotic component. Habitat preferences identified through analysis of factors related to fish abundance by principal component analysis method. The results showed that on those artificial reefs in Awang and Bumbang Bay found as many as $8-16$ species of coral fish belongs to 15 families, dominated by Apogonidae (Archamia fucata), Pomacentridae (Neopomacentrus cyanomos) and Phempherididae (Phempheris oulensis), ranges of the abundance 268 to1088 individual. The ecological index showed low to moderate type of diversity, the dominance index does not indicate the dominance of certain species and the evenness index indicated that the fish dispersal characteristic is quite flat. Fish habitat preference in Awang Bay supported by the presence of algae and other biota, nutrients, and salinity. While in Teluk Bumbang supported by the abundance of fito-zooplankton, dissolved oxygen, and turbidity.

Keywords: Community structure, coral fish, artificial reef, Awang Bay, Bumbang Bay, habitat preferences

\section{Pendahuluan}

Ekosistem terumbu karang merupakan karakter dominan pada perairan dangkal di daerah beriklim tropis dan subtropis baik dari segi ekologis maupun geologis (Hallock, 2009). Luasan terumbu karang di Indonesia mencapai 2,5 juta hektar, sebanyak $10,8 \%$ terletak di perairan Nusa Tenggara (Giyanto et al., 2017). Kedinamisan perubahan terumbu karang sangat dipengaruhi oleh lingkungan dan aktivitas manusia dengan intensitas yang berbeda sesuai waktu dan lokasi tumbuhnya. Terumbu karang merupakan pusat keanekaragaman hayati laut karena merupakan habitat pemijahan, peneluran, pembesaran anak, makan dan mencari makan (feeding \& foraging) bagi banyak spesies biota laut. Fungsi lainnya sebagai sumber penting berbagai bahan bioaktif yang diperlukan di bidang medis dan farmasi, juga sebagai pelindung garis pantai, padang lamun dan hutan mangrove dari arus dan gelombang besar. Ancaman dan permasalahan yang terjadi pada terumbu karang tidak terlepas dari dampak aktivitas manusia dan aktivitas geologi alamiah bumi dan kondisi masing-masing wilayah (Giyanto et al., 2017). Berdasarkan data LIPI tahun 2016, status terumbu karang di wilayah Lombok tergolong cukup hingga buruk (Giyanto et al., 2017). Degradasi habitat terumbu karang berdampak serius terhadap perikanan artisanal dan sistem yang mensuplai kehidupan terumbu karang (Munday et al., 2008; Cinner et al., 2012). Kerusakan terumbu karang juga berdampak pada terjadinya degradasi habitat dan sumberdaya lobster. Sebagai contoh, dalam kurun waktu enam tahun (2006 - 2012) terjadi penurunan produksi lobster di Nusa Tenggara Barat sebesar 80\% (Giyanto et al., 2017). Penyebab penurunan produksi tersebut diduga karena degradasi terumbu karang serta tingkat pemanfaatan juvenil lobster yang tinggi. Dalam upaya merehabilitasi ekosistem yang rusak tersebut, penempatan terumbu karang buatan diyakini mampu mengembalikan fungsi ekosistem tersebut.

Pemikiran mengenai perlunya suatu benda untuk menarik obyek dalam air telah ada sejak awal abad ke-18, yang kemudian dipelopori oleh Jepang dalam hal pengembangannya, dan disusul oleh negara-negara di Amerika, Eropa dan Asia (Hartati, 2008). Di Indonesia, terumbu buatan mulai berkembang sejak tahun 1970 (Hartati, 2008). Terumbu buatan merupakan suatu benda yang ditempatkan di dasar perairan sebagai habitat buatan dengan meniru karakteristik terumbu alami (Christy, 1991; Hutomo, 1991). Materi pembentuk terumbu buatan bisa beranekaragam dengan memperhitungkan aspek-aspek positif dari material tersebut (de Silva, 1989). Tujuan pembuatan terumbu karang buatan antara lain mempertahankan stok ikan tertentu yang merupakan target eksploitasi, mengkonservasi secara biologi baik terumbu karang maupun komunitas yang berasosiasi dengannya (seperti makroalga, invertebrata dan ikan) (Carr \& Hixon, 1997; Seaman, 2000).

Pada tahun 2014 telah dilakukan penempatan terumbu buatan di Teluk Awang dan Teluk Bumbang masing-masing sebanyak dua buah (Sumiono et al., 2014). Tujuan penempatan 
tersebut adalah untuk memulihkan kondisi habitat sumber daya ikan melalui rekayasa habitat Penempatan lokasi terumbu buatan di Teluk Awang dan di Teluk Bumbang dilatarbelakangi oleh kondisi terumbu karang yang telah mengalami kerusakan.

Dalam rangka mengevaluasi dampak dari kegiatan penempatan terumbu buatan di Teluk Awang dan Teluk Bumbang, Faizah et al. (2015) telah melakukan monitoring perkembangan spesies yang berasosiasi dengan terumbu tersebut. Adapun tujuan dari penelitian ini adalah untuk mengetahui struktur komunitas dan preferensi habitat ikan karang di kedua terumbu buatan tersebut. Hasil yang diperoleh akan melengkapi informasi perkembangan terumbu buatan di Teluk Awang dan Teluk Bumbang.

\section{Metodologi}

\section{Lokasi dan Waktu}

Penelitian dilakukan di lokasi penempatan terumbu buatan di Teluk Awang dan Teluk Bumbang, Kabupaten Lombok tengah, Propinsi Nusa Tenggara Barat (Gambar 1). Terdapat dua terumbu karang buatan di masing-masing lokasi, sehingga secara keseluruhan terdapat sejumlah empat titik terumbu karang buatan. Waktu pelaksanaan monitoring dilakukan pada bulan Juni dan Desember 2015.

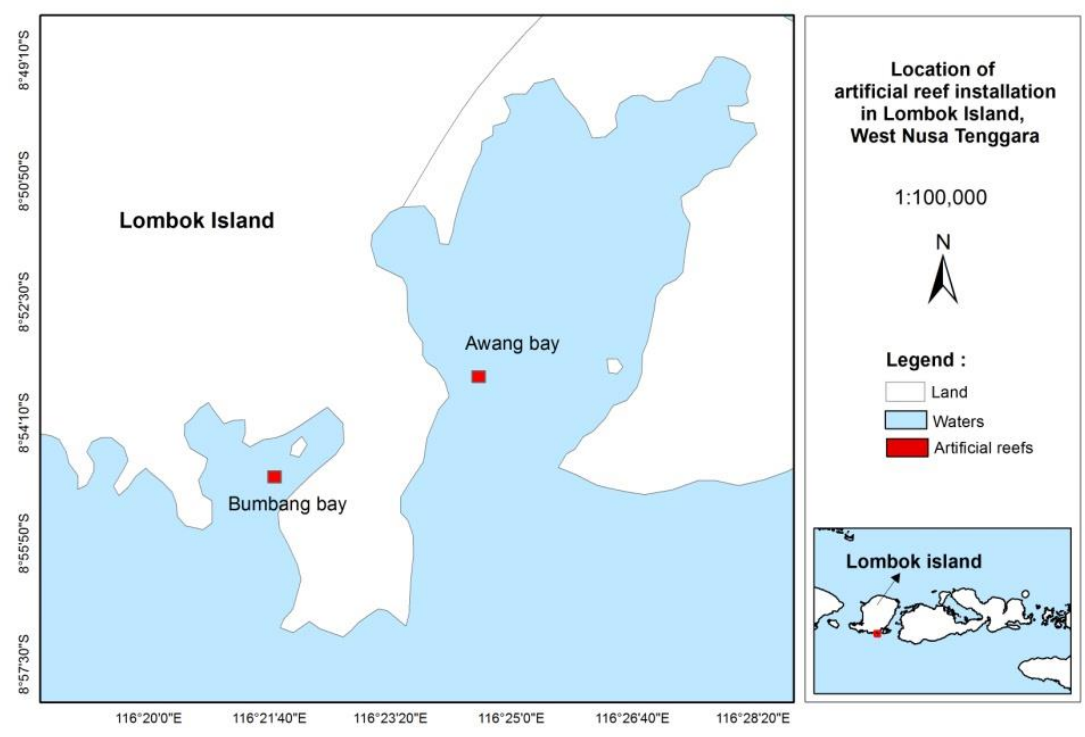

Gambar 1. Lokasi penelitian di Teluk Awang dan Bumbang.

Figure 1. Site sampling in Awang Bay and Bumbang Bay.

\section{Pengumpulan Data}

Pengambilan data meliputi komunitas ikan dan komunitas bentik (meliputi karang keras yang merupakan karang hidup atau life coral, karang mati atau dead coral, algae; komponen abiotik seperti pasir, pecahan karang atau rubble, lanau atau silt, dan batu atau rock; serta fauna lainnya seperti Ascidian, karang lunak dan teritip), parameter biologi (fitoplankton, zooplankton, meroplanton), parameter fisik (suhu, salinitas, konduktivitas, $\mathrm{pH}, \quad$ kekeruhan, oksigen terlarut/DO) serta parameter kimia/unsur hara perairan (nitrat dan fosfat).

Data ikan karang dan komunitas bentik diperoleh melalui penggunaan peralatan selam SCUBA (Self Contained Underwater Breathing
Apparatus), underwater sheet dan pensil untuk mencatat ikan pada waktu pengamatan, GPS (Global Positioning System) untuk mencari posisi titik penenggelaman terumbu buatan, dan underwater camera. Komunitas ikan didata secara visual menggunakan modifikasi teknik stationary visual census (English et al., 1997). Komunitas bentik didata secara visual di lokasi terumbu buatan.

Pengukuran parameter fisik dilakukan secara in situ pada permukaan dan dasar perairan (kedalaman 9 dan $11 \mathrm{~m}$ ) menggunakan alat water quality checker. Pengambilan sampel fitoplankton dan zooplankton menggunakan plankton net $60 \mu$ dan $300 \mu$, sedangkan meroplankton menggunakan jaring bonggo $700 \mu$. Kemudian pemeriksaan secara laboratorium dilakukan untuk 
unsur hara seperti nitrat dan fosfat serta plankton dan meroplankton.

\section{Analisis Data}

Analisis keragaman hayati ikan karang menggunakan beberapa indeks ekologi yaitu Indeks Dominasi, Indeks Keanekaragaman dan Indeks Keseragaman Jenis (Ludwig \& Reynold, 1988), dengan formula sebagai berikut:

a. Indeks keanekaragaman $\left(\mathrm{H}^{\prime}\right)$

$$
H^{\prime}=-\sum_{i=i}^{n} P i(\log 2 P i)
$$

Keterangan :

$\mathrm{H}^{\prime}=$ Indeks keanekaragaman ShannonWiever

$\mathrm{Pi}=$ Perbandingan jumlah spesies ke-i terhadap keseluruhan spesies

$\mathrm{n}=$ Jumlah spesies

Kategori berdasarkan nilai indeks keanekaragaman (H') (Odum, 1971):

$\mathrm{H}^{\prime} \leq 1$ : Keanekeragaman jenis kecil, tekanan ekologis sangat kuat.

$1<\mathrm{H}^{\prime} \leq 3$ : Keanekeragaman jenis sedang

$\mathrm{H}^{\prime}>3$ : Keanekeragaman jenis, terjadi keseimbangan ekosistem

b. Indeks keseragaman (E)

Perhitungan indeks keseragaman modifikasi eveness (Odum, 1971) :

$$
\boldsymbol{E}=\frac{\boldsymbol{H}^{\prime}}{\boldsymbol{H}_{\text {maks }}}
$$

Keterangan :

$\mathrm{E}=$ Indeks keseragaman (equitaility)

$\mathrm{H}^{\prime}=$ Indeks keanekaragaman

$\mathrm{H}_{\text {maks }}=$ Keanakeragaman spesies dalam keseimbangan maksimum

Indeks keseragaman menunjukkan distribusi jumlah individu dalam setiap yang ada. Indeks keseragaman mempunyai nilai berkisar antara $0-1$ dengan kisaran (Odum, 1971), yaitu : $\mathrm{E} \leq 0,4 \quad$ : Keseragaman jenis rendah $0,4<\mathrm{E} \leq 0,6$ : Keseragaman jenis sedang $\mathrm{E}>0,6$ : Keseragaman jenis tinggi

c. Indeks dominansi (C)

Untuk melihat adanya dominansi suatu spesies tertentu di dalam komunitas ikan karang digunakan Indeks Dominansi Simpson (Odum, 1971) dengan rumus :

$$
C=\sum_{i=1}^{s}\left(\frac{n_{i}}{N}\right)^{2}
$$

Keterangan :

$\mathrm{C}=$ Indeks dominansi Simpson

$\mathrm{ni}=$ Jumlah Individu jenis ke-i

$\mathrm{N}=$ Jumlah total individu

Analisis komponen utama (Principle Component Analysis) menggunakan software SPSS IBM 22.0, untuk melihat kaitan antara parameter (fisik dan biologi) dengan kelimpahan ikan karang. Seleksi dan pengukuran variabel, dalam penelitian ini menggunakan 11 parameter, meliputi suhu, salinitas, oksigen terlarut, kekeruhan, kelimpahan fito-zooplankton, meroplankton terutama cacing laut (polichaeta), nitrat, fosfat, tutupan alga dan biota lain. Melakukan standarisasi data melalui transformasi skala-Z, karena variasi satuan dari masing-masing parameter. Analisis deskriptif terhadap data yang dikumpulkan selama pelaksanaan penelitian untuk memperoleh gambaran umum tentang kondisi habitat di sekitar terumbu buatan.

\section{Hasil}

\section{Struktur Komunitas Ikan Karang}

Ikan karang yang ditemukan di lokasi penelitian terdiri dari 8 - 16 spesies dari 15 famili. Di Teluk Awang dijumpai 8 - 11 spesies dari 7 - 9 famili, sementara di Teluk Bumbang dijumpai 12 - 16 spesies dari 8 - 10 famili. Apogonidae (46 $61 \%)$, Pomacentridae $(14-18 \%)$ dan Phempherididae (23 - 28\%) merupakan famili yang paling dominan. (Gambar 2, Tabel 1).

Di Teluk Awang dijumpai satu spesies ikan yang dikategorikan sebagai ikan ekonomis atau ikan target, satu spesies ikan indikator dan 7 9 spesies ikan mayor, pada pengamatan bulan Juni dan Desember (Tabel 1). Sementara di Teluk Bumbang dijumpai 2 - 4 spesies ikan target, satu 1 - 2 spesies ikan indikator dan 8 - 11 spesies ikan mayor, pada pengamatan bulan Juni dan Desember (Tabel 1).

Ikan yang dominan di kedua teluk tersebut pada bulan Juni dan Desember adalah Archamia fucata dan Neopomacentrus cyanomos yang keduanya merupakan ikan mayor. Ikan target dominan dijumpai di Teluk bumbang baik pada bulan Juni maupun Desember yaitu Plectorhynchus gibbosus dan yuwana ikan Lutjanus quenquelineatus. Ikan indikator dominan dijumpai di Teluk Bumbang baik pada bulan Juni maupun Desember berasal dari jenis Heniochus acuminatus dan Pterois antennata. Kelimpahan 
ikan karang di Teluk Awang berada dalam kisaran 604 - 1028 ekor, sementara di Teluk Bumbang sekitar 268 - 478 ekor. Konsistensi kelimpahan ikan di Teluk Awang terjadi pada terumbu buatan di lokasi pertama atau dengan kata lain kelimpahan yang relatif tinggi selalu ditemukan pada terumbu buatan di lokasi pertama baik pada bulan Juni maupun Desember, yaitu 1027 - 1028 ekor. Sedangkan di Teluk Bumbang, kelimpahan relatif tinggi terjadi pada bulan Desember (297 478 ekor) (Gambar 3).

\section{Indeks Ekologi}

Indeks kekayaan ikan karang dalam suatu komunitas serta keseimbangan jumlah individu tiap jenis menunjukkan beberapa hal yang tidak berbeda nyata secara signifikan $(\mathrm{p}>0,05)$ dalam ekosistem terumbu karang buatan di Teluk Awang dan Teluk Bumbang. Indeks keanekaragaman $\left(\mathrm{H}^{\prime}\right)$ menunjukkan bahwa struktur komunitas ikan karang pada dua lokasi terumbu buatan di Teluk Bumbang pada bulan Juni dan Desember tergolong memiliki keanekaragaman sedang (1 < $\mathrm{H}<3$ ), demikian halnya pada terumbu buatan di lokasi pertama di Teluk Awang. Namun pada terumbu buatan di Teluk Awang pada bulan Juni menunjukkan keanekaragaman jenis rendah $(\mathrm{H}<1)($ Tabel 2).

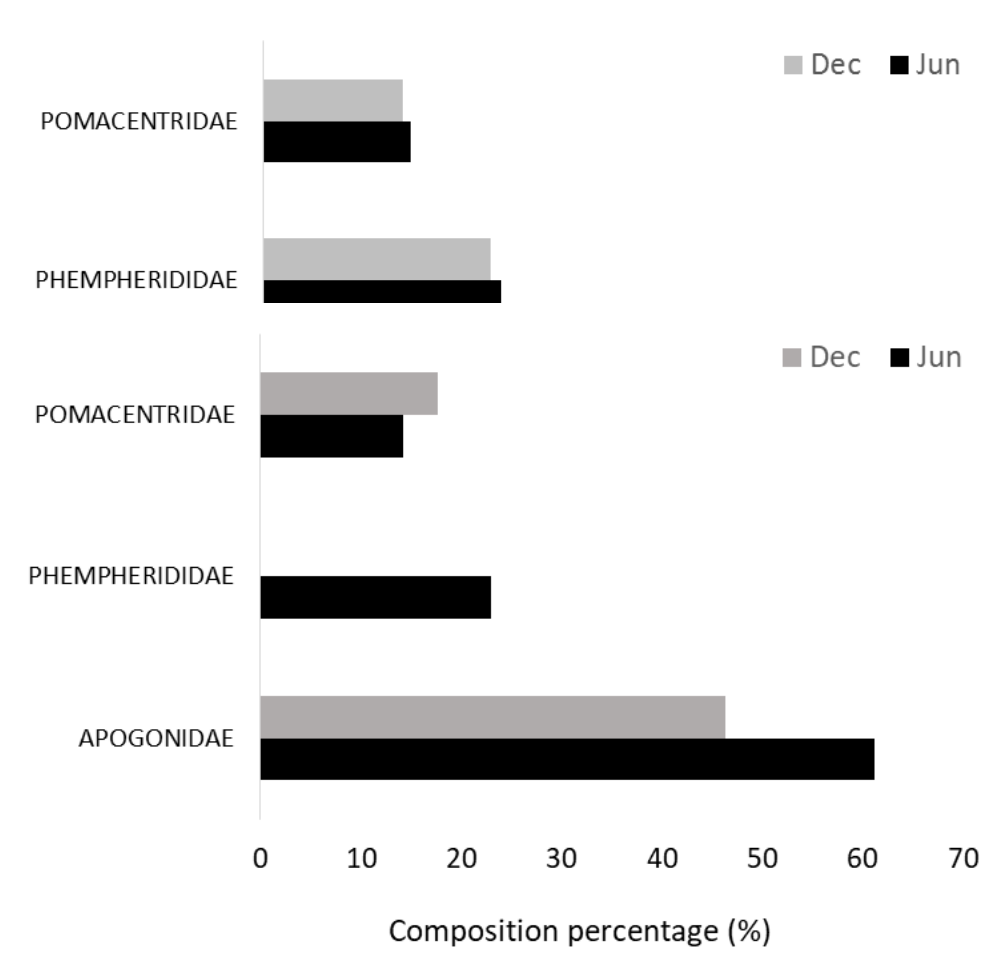

Gambar 2. Komposisi ikan karang berdasarkan famili, Teluk Awang (atas) dan Teluk Bumbang (bawah). Figure 2. Reef fishes composition based on family, Awang Bay (upper) dan Bumbang Bay (below).

Tabel 1. Jumlah famili ikan karang di Teluk Awang dan Teluk Bumbang berdasarkan kelompok ikan. Table 1. The number of families of reef fishes in Awang Bay and Bumbang Bay based on the fish group.

\begin{tabular}{lcccc}
\hline \multirow{2}{*}{ Fish Group } & \multicolumn{2}{c}{ Awang Bay } & \multicolumn{2}{c}{ Bumbang Bay } \\
\cline { 2 - 5 } & June & December & June & December \\
\hline Mayor Fish & 8 & 8 & 9 & 10 \\
Target Fish & 1 & 1 & 3 & 3 \\
Indicator Fish & 1 & 1 & 2 & 1 \\
\hline
\end{tabular}

Remarks: average value from both artificial reefs 


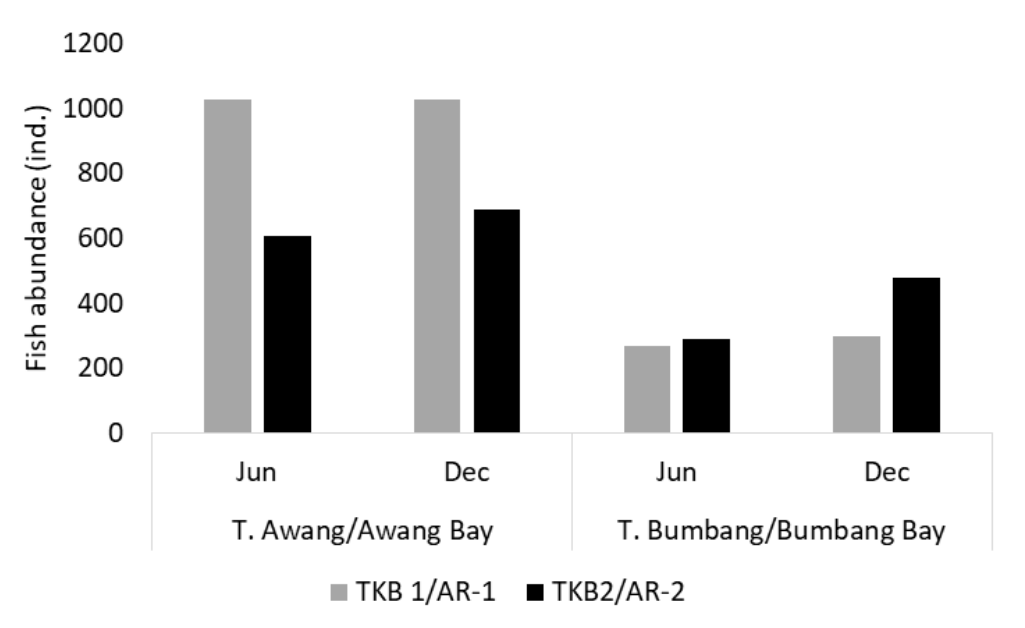

Keterangan/Remarks: terumbu karang buatan (TKB)/artificial reef (AR)

Gambar 3. Kelimpahan ikan di lokasi terumbu buatan Teluk Awang dan Teluk Bumbang.

Figure 3. Fish abundance in artificial reefs Awang Bay and Bumbang Bay.

Tabel 2. Indeks-indeks biologi.

Table 2. Biological index.

\begin{tabular}{|c|c|c|c|c|c|c|c|c|}
\hline \multirow[b]{3}{*}{ Biological Index } & \multicolumn{4}{|c|}{ June } & \multicolumn{4}{|c|}{ December } \\
\hline & \multicolumn{2}{|c|}{ Awang bay } & \multicolumn{2}{|c|}{ Bumbang bay } & \multicolumn{2}{|c|}{ Awang bay } & \multicolumn{2}{|c|}{ Bumbang bay } \\
\hline & $\begin{array}{c}\text { TKB 1/ } \\
\text { AR1 }\end{array}$ & $\begin{array}{c}\text { TKB } \\
2 / \\
\text { AR2 }\end{array}$ & $\begin{array}{c}\text { TKB } \\
1 / \\
\text { AR1 }\end{array}$ & $\begin{array}{c}\text { TKB } \\
2 / \\
\text { AR2 }\end{array}$ & $\begin{array}{c}\text { TKB } \\
1 / \\
\text { AR1 }\end{array}$ & $\begin{array}{c}\text { TKB 2/ } \\
\text { AR2 }\end{array}$ & $\begin{array}{c}\text { TKB 1/ } \\
\text { AR1 }\end{array}$ & $\begin{array}{c}\text { TKB } \\
2 / \\
\text { AR2 }\end{array}$ \\
\hline Diversity index & 1,17 & 0,99 & 1,36 & 1,71 & 1,17 & 1,10 & 1,25 & 1,62 \\
\hline Eveness index & 0,41 & 0,45 & 0,45 & 0,24 & 0,41 & 0,43 & 0,49 & 0,28 \\
\hline Similarity index & 0,35 & 0,29 & 0,40 & 0,51 & 0,34 & 0,32 & 0,37 & 0,48 \\
\hline
\end{tabular}

Remarks $: \mathrm{TKB}=$ terumbu karang buatan/AR $=$ artificial reef

Indeks kemerataan menunjukkan bahwa pola penyebaran ikan pada terumbu buatan di Teluk Bumbang dan Teluk Awang tergolong merata $(0,29$ - 0,51), baik pada bulan Juni maupun Desember. Indeks dominansi spesies menunjukan kisaran 0,24 - 0,49 yang artinya tidak terjadi dominansi spesies tertentu terhadap spesies lain baik pada terumbu buatan di Teluk Awang maupun di Teluk Bumbang.

\section{Kondisi Habitat dan Lingkungan}

Parameter lingkungan di lokasi penempatan terumbu buatan menunjukkan bahwa salinitas di Teluk Awang lebih tinggi daripada di Teluk Bumbang, yaitu 34,6 ppt dan 33 ppt. Parameter kecerahan Teluk Awang jauh lebih rendah atau sama dengan 4,9 $\mathrm{m}$ dibandingkan dengan di Teluk Bumbang sebesar 10,5 m. Suhu permukaan dan dasar perairan Teluk Awang relatif lebih rendah dibandingkan dengan perairan Teluk Bumbang. Demikian halnya dengan oksigen terlarut antara di bagian permukaan dan dasar perairan (kedalaman 9 dan $11 \mathrm{~m}$ ), bahwa kadar nilai oksigen terlarut di Teluk Awang lebih rendah dibandingkan dengan di Teluk Bumbang. Hal sebaliknya terjadi pada besarnya konduktivitas perairan, TDS (Total Dissolved Solids atau padatan terlarut) dan $\mathrm{pH}$, dimana pada Teluk Awang lebih tinggi dibandingkan dengan Teluk Bumbang (Tabel 3). 
Tabel 3. Parameter lingkungan di terumbu buatan di Teluk Awang dan Bumbang.

Table 3. Environmental parameters on artificial reefs in Awang and Bumbang Bay.

\begin{tabular}{lcc}
\hline \multicolumn{1}{c}{ Environmental parameters } & Awang Bay & Bumbang Bay \\
\hline Salinity (ppt) & 34,6 & 33 \\
Transparancy $(\mathrm{m})$ & 4,9 & 10,5 \\
Depth $(\mathrm{m})$ & 9,6 & 11 \\
Surface temperature $\left({ }^{\circ} \mathrm{C}\right)$ & 28,09 & 30,2 \\
Bottom teperature $\left({ }^{\circ} \mathrm{C}\right)$ & 27,88 & 29,8 \\
Dissolve Oxigen $($ satuan) & & \\
Surface (mg/l) & $5,46-5,68$ & 5,6 \\
Bottom (mg/l) & $5,21-5,22$ & 5,78 \\
Surface conductivity (satuan) & 52,5 & 41,8 \\
Bottom conductivity & 52,6 & 42,1 \\
Turbidity (satuan) & & 8,8 \\
Surface TSS & 31,3 & 31,2 \\
Bottom TSS & 31,3 & 31,6 \\
Surface pH & $8,05-8,26$ & 8,01 \\
Bottom pH & $8,23-8,26$ & 8,02 \\
Nitrate (satuan) & $0-0,053$ & 0,017 \\
Fosfate (satuan) & $0,009-0,018$ & 0,014 \\
\hline
\end{tabular}

Kelimpahan fito-zooplankton di sekitar lokasi penempatan terumbu buatan menunjukan bahwa proporsi di Teluk Bumbang lebih tinggi jika dibandingkan dengan di Teluk Awang (Gambar 4). Kelimpahan fito-zooplankton pada bulan Juni di Teluk Bumbang berada dalam kisaran 3,266 individu/L dan 0,247 individu/L. Sementara pada di Teluk Awang, fitoplankton berkisar 1,061 individu/L dan zooplankton berkisar 0,140 individu/L.

Meroplankton yang dijumpai pada terumbu buatan di Teluk Awang dan Teluk Bumbang terdiri atas ikan, telur ikan, udang, kepiting dan cacing laut (polichaeta) (Gambar 5). Dari lima meroplankton yang dijumpai, telur ikan merupakan yang paling dominan, disusul oleh kepiting dan udang. Larva ikan dijumpai dalam jumlah yang sangat sedikit, demikian hal-nya dengan cacing laut, namun kelimpahan larva ikan di Teluk Awang relatif lebih banyak (TBK1 = 11 individu; $\mathrm{TBK} 2=2$ individu) dibandingkan dengan di Teluk Bumbang (TBK1 = 2 individu; TBK2 = 4 individu). Kelimpahan telur ikan tertinggi terjadi baik pada terumbu buatan di Teluk Awang (TBK 1 = 2749 individu; TBK2 = 1307 individu) maupun di Teluk Bumbang (TBK1 $=1375$ individu; TBK2 = 2191 individu). Keberadaan cacing laut dijumpai melimpah hanya di terumbu buatan di Teluk Awang, dan tidak dijumpai di Teluk Bumbang. Kelimpahan meroplankton secara keseluruhan di Teluk Awang lebih tinggi dibandingkan dengan di Teluk Bumbang, yaitu masing-masing 4948 dan 4574 individu
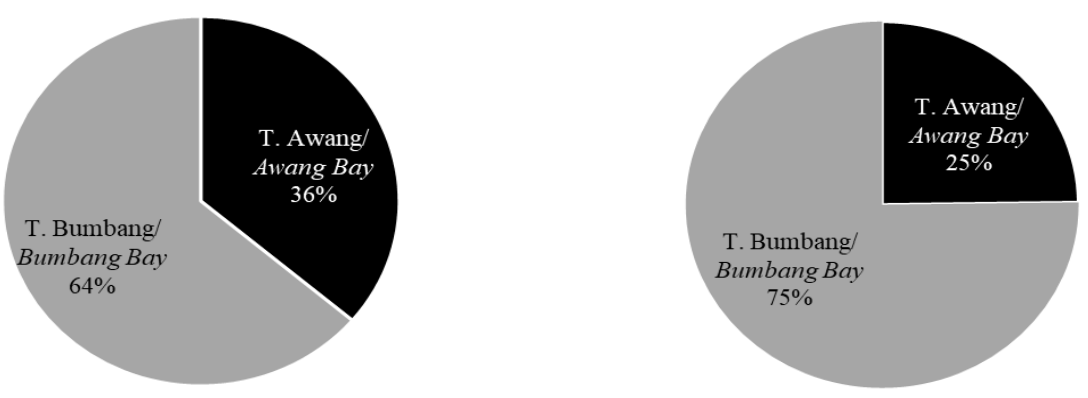

Gambar 4. Kelimpahan zooplankton (kiri) dan fitoplankton (kanan).

Figure 4. Zooplankton abundance (left) and fitoplankton abundance (right). 


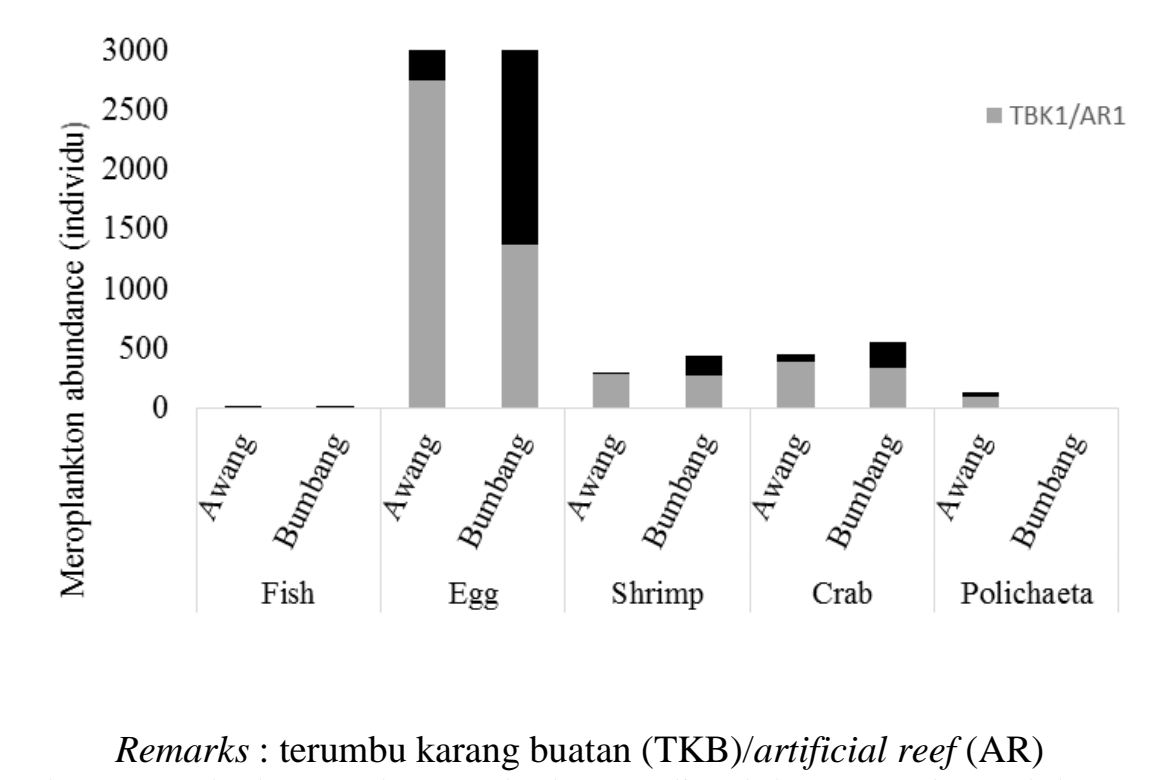

Gambar 5. Kelimpahan meroplankton pada terumbu buatan di Teluk Awang dan Teluk Bumbang.

Figure 5. Type and abundance of meroplankton on artificial reefs in Awang Bay and Bumbang Bay.

\section{Persentase Tutupan Karang}

Persentase tutupan karang pada terumbu buatan dikategorikan ke dalam lima kriteria tutupan, yaitu karang keras (hard coral), karang mati, alga, biota lainnya (Ascidian, karang lunak dan teritip), serta abiotik. Tutupan karang pada terumbu buatan di Teluk Awang meliputi karang keras sebesar $0 \%$ dan karang mati sebesar $0 \%$ baik pada pengamatan bulan Juni maupun Desember. Tutupan biota yang meliputi alga dan biota lainnya masing-masing terdiri atas 59,16 $59,26 \%$ (Juni) dan 51,91 - 54,26\% (Desember) untuk alga, biota lainnya sebesar 6,49 - 45,74\% (Juni) dan 14,12 - 45,74\% pada Desember. Tutupan abiotik meliputi 0 - 34,35\% (Juni) dan 14,12 - 45,74\% (Desember).

Tutupan karang pada terumbu buatan di Teluk Bumbang masih 0\%, baik untuk karang keras dan karang mati pada bulan Juni maupun Desember. Tutupan alga di semua stasiun penelitian berkisar antara $19,31-65,60 \%$ pada bulan Juni dan 19,31 - 42,66\% pada bulan Desember. Biota lainnya seperti Ascidian, karang lunak dan teritip, ditemukan berkisar antara 0,93 $34,4 \%$ pada bulan Juni dan 0,93 - 25,78\% pada bulan Desember. Komponen abiotik seperti pasir, pecahan karang (rubble), lanau (silt), batu (rock) ditemukan dengan tutupan sebesar $0-79,75 \%$ pada bulan Juni dan 31,56 - 79,75\% pada bulan Desember.

\section{Faktor-faktor Terkait Kelimpahan Ikan Karang}

Analisis komponen utama (PCA) dilakukan terhadap 11 parameter dengan tujuan untuk menganalisis faktor-faktor yang berhubungan dengan kelimpahan ikan karang. Dari 11 komponen utama tersebut, hanya dua komponen yang berperan penting dengan nilai akar ciri (eigenvalue) $>1$ (PC > 1) (Gambar 6). PC 1 berkontribusi sebesar $64 \%$ dari total ragam, juga merupakan interaksi lima parameter yaitu oksigen terlarut, kelimpahan fitoplankton, turbiditas, tutupan alga dan kelimpahan zooplankton, dengan nilai terbesar adalah kelimpahan fitoplankton (Tabel 4). PC2 berkontribusi sebesar 36\% dari total ragam, merupakan interaksi empat parameter yaitu salinitas, nitrat, fosfat dan tutupan biota lainnya. Nilai muatan terbesar adalah kandungan fosfat (Tabel 4). 
Tabel 4. Hasil analisis komponen utama, nilai akar ciri, variabilitas, dan ragam kumulatif terkait kelimpahan ikan karang.

Table 4. Results of principal component analysis, eigenvalues, variability, and cumulative of variance related to reef fishes abundance.

\begin{tabular}{lrr}
\hline \multirow{2}{*}{ Variable } & \multicolumn{2}{c}{ Component } \\
\cline { 2 - 3 } & 1 & 2 \\
\hline Temperature & -.945 & -.327 \\
Salinity & -.130 & $\mathbf{. 9 9 2}$ \\
DO & $\mathbf{. 9 4 3}$ & -.334 \\
Zooplankton & $\mathbf{. 8 9 1}$ & -.453 \\
Fitoplankton & $\mathbf{. 9 9 3}$ & .117 \\
Polychaeta & -.924 & .384 \\
Nitrate & -.328 & $\mathbf{. 9 4 5}$ \\
Phosphate & -.028 & $\mathbf{1 . 0 0 0}$ \\
Turbidity & $\mathbf{9 9 2}$ & .130 \\
Algae & $\mathbf{9 5 1}$ & -.310 \\
Other Biota & .109 & $\mathbf{. 9 9 4}$ \\
\hline
\end{tabular}

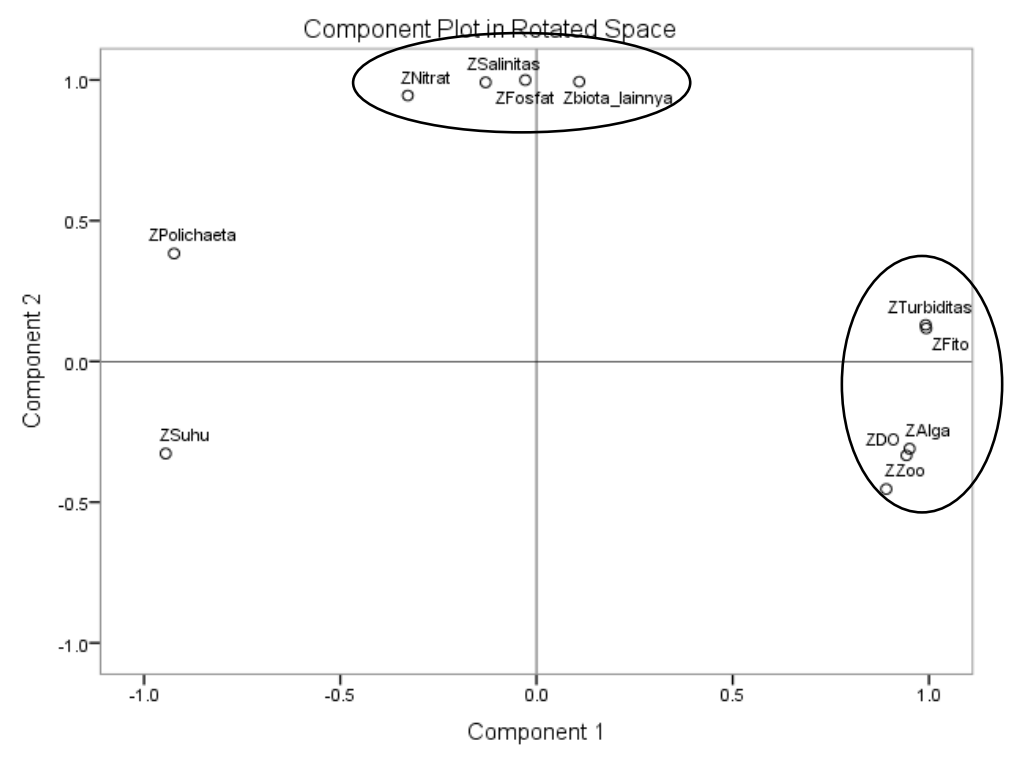

Gambar 6. Plot analisis komponen utama berdasarkan parameter pendukung kelimpahan ikan karang.

Figure 6. Principal component analysis plot related to reef fishes abundance.

\section{Pembahasan}

\section{Struktur Komunitas}

Jumlah spesies dan famili ikan karang yang dijumpai pada terumbu buatan di Teluk Awang dan Teluk Bumbang relatif rendah (8 - 16 spesies dari 15 famili) (Tabel 1), jika dibandingkan dengan komunitas ikan karang di beberapa terumbu buatan di perairan Indonesia. Jumlah ikan yang rendah tersebut diduga disebabkan oleh pelaksanaan monitoring yang berdekatan dengan waktu pemasangan terumbu buatan (satu tahun setelahnya). Beberapa spesies ikan yang terdapat di lingkungan terumbu karang merupakan indikator terpenuhinya kriteria habitat yang mampu medukung perkembangan biota asosiasi karang termasuk berbagai spesies ikan di lingkungan tersebut. Faktor lain yang mempengaruhi keanekaragaman dan jumlah individu ikan adalah kondisi terumbu karang dan lingkungan perairan yang baik (Tarigan et al., 2009). Berdasarkan dua referensi tersebut dapat dikatakan bahwa kondisi perairan Teluk Awang dan Teluk Bumbang cukup baik untuk mendukung perkembangan terumbu buatan (Tabel 3). Sebagai gambaran, di perairan Nusa Tenggara 
Barat terdapat 20-59 spesies dari 10 - 28 famili ikan karang di lokasi terumbu buatan (Satria \& Mujiyanto, 2011; Sentosa \& Satria, 2011; Mujiyanto \& Sugianti, 2014). Sementara pada terumbu buatan di sekitar perairan Pulau Seribu dijumpai 29 - 68 spesies dari 11 - 25 famili ikan karang (Dhahiyat et al., 2003; Kusnanto, 2015; Pardede, 2012). Di Perairan Buleleng, Bali utara yang merupakan lokasi terumbu alami terluas di wilayah Bali yang mengalami kerusakan tercatat hanya 38 spesies dari 18 famili ikan karang yang dijumpai pada terumbu buatan (Yunaldi et al., 2011). Tercatat bahwa komunitas ikan karang pada terumbu buatan di perairan Situbondo tergolong tinggi yaitu 72 spesies dari 24 famili (Yanuar \& Aunurohim, 2015), sementara di perairan di Wilayah Kupang sejumlah 47 spesies dari 14 famili (Lauwoie, 2010).

Kelimpahan Famili Apogonidae dan Pomacentridae yang terdiri atas ikan mayor serta Phempherididae yang terdiri atas ikan target adalah kondisi yang umum terjadi di beberapa terumbu buatan. Famili Pomacentridae merupakan yang umum ada di perairan tropis dan subtropis atau perairan Indo Pasifik termasuk Indonesia (Fricke, 1977; Hobson, 1991; Romimohtarto \& Juwana, 2001). Di samping tiga famili tersebut, kelimpahan Labridae (kelompok ikan mayor) dan Caesionidae (kelompok ikan target) pada umumnya juga merupakan famili yang dominan di beberapa terumbu buatan di perairan di Indonesia.

Berdasarkan pengelompokan ikan karang menurut English et al. (1997), kelimpahan individu ikan mayor (ikan berukuran kecil dan sering dijumpai) relatif lebih tinggi pada terumbu karang buatan di Teluk Bumbang, walaupun tidak berbeda secara signifikan dengan yang dijumpai di Teluk Awang. Kelimpahan ikan mayor di Teluk Bumbang yang lebih tinggi jika dibandingkan dengan di Teluk Awang juga terjadi pada ikan target (ikan ekonomis penting dan biasa ditangkap untuk konsumsi) dan ikan indikator (ikan yang khas mendiami daerah terumbu karang dan menjadi indikator kesuburan ekosistem daerah tersebut). Ikan mayor dan ikan target pada umumnya selalu mendominasi suatu ekosistem terumbu karang buatan maupun alami, dalam artian tidak ada perbedaan signifikan terhadap kelimpahan antara kedua kelompok jenis tersebut di suatu habitat karang.

\section{Kelimpahan Individu dan Tinjauan Preferensi Habitat}

Kelimpahan individu ikan karang pada terumbu buatan di Teluk Awang jauh lebih tinggi jika dibandingkan dengan terumbu buatan di Teluk Bumbang. Analisis komponen utama terhadap 11 parameter (suhu, salinitas, DO, fitoplankton, zooplankton, turbiditas, tutupan alga, tutupan biota lain, nitrat dan fosfat serta kelimpahan polichaeta) merujuk pada keberadaan ikan karang yang dipengaruhi oleh kondisi atau kualitas karang sebagai habitatnya (Dartnall \& Jones, 1986; Choat \& Bellwood, 1991; Kuiter, 1992).

Analisis PCA menghasilkan sembilan variabel yang paling berkaitan dengan kelimpahan ikan karang pada terumbu buatan di Teluk Awang dan Teluk Bumbang, yaitu salinitas, DO, fitoplankton, zooplankton, turbiditas, tutupan alga, tutupan biota lain, nitrat dan fosfat. Dalam penelitian ini, suhu dan cacing laut (polichaeta) memiliki nilai akar ciri rendah (ragam dari kombinasi komponen), atau dalam arti baik cacing laut maupun suhu bukan merupakan komponen utama sehingga berdiri sendiri atau terpisah. Berdiri sendirinya kedua variabel tersebut dalam kajian ini sedikit berlawanan dengan data dan teori mengenai kaitan keduanya terhadap kondisi tutupan komunitas karang, padahal dalam Dee \& Parish (1994), Bailey-Brock (2003), dan Takada (2012) dinyatakan bahwa cacing laut (Polichaeta) sebagaimana diketahui merupakan hewan bentik yang juga sebagai makanan bagi sebagian besar ikan karang dan makro invertebrate. Kisaran suhu di kedua lokasi menunjuk, an kondisi baik bagi pertumbuhan terumbu karang sebagaimana dinyatakan Supriharyono (2000), bahwa kisaran suhu yang baik untuk pertumbuhan terumbu karang adalah $25-29^{\circ} \mathrm{C}$ dan atau $14-30^{\circ} \mathrm{C}$ (Hallock, 2009). Sementara pada terumbu buatan di Teluk Awang, kelimpahan meroplankton (ikan, telur, udang, kepiting dan polichaeta) bisa dikatakan sebagai penyebab lain terjadinya kelimpahan ikan karang.

Konsistensi parameter yang terkait dengan kelimpahan ikan karang melalui analisis deskriptif dan PCA ditunjukkan dengan keanekaragaman spesies dan famili, jenis ikan mayor, ikan target dan ikan indikator yang relatif tinggi di Teluk Bumbang dibandingkan dengan di Teluk Awang. Kelimpahan jenis tersebut tergambarkan dalam indeks keanekaragaman, dimana di Teluk Bumbang tergolong sedang sementara di Teluk Awang tergolong rendah. Secara deskriptif, kandungan oksigen terlarut, kelimpahan fito-zooplankton dan turbiditas relatif tinggi di Teluk Bumbang. Demikian pula dengan aplikasi PCA yang menunjukkan bahwa empat parameter tersebut berkontribusi besar (PC $1=$ 64\%) terhadap kelimpahan jenis ikan karang pada kasus di Teluk Bumbang (tutupan alga merupakan parameter yang berkontribusi paling besar akan dibahas pada kasus di Teluk Awang karena 
tutupan alga tinggi di perairan ini (Gambar 6). Jika ditinjau dari kelimpahan plankton baik zooplankton maupun fitoplankton, terlihat bahwa preferensi habitat ikan karang di Teluk Bumbang disebabkan oleh ketersediaan makanan, karena kelimpahan fito dan zooplankton di Teluk Bumbang lebih tinggi secara signifikan $(\mathrm{p}<0.005)$ (Gambar 4).

Beberapa parameter yang terkait dengan kelimpahan ikan karang melalui analisis deskriptif dan PCA ditunjukkan dengan komponen PC 2 yang terdiri atas parameter salinitas, nitrat, fosfat dan biota lainnya sebesar 36\% (Gambar 6), yang juga didukung oleh hasil analisis secara deskriptif dari beberapa parameter tersebut terhadap kelimpahan individu ikan karang di Teluk Awang. Salinitas perairan di sekitar terumbu buatan di Teluk Awang lebih tinggi dibandingkan dengan di Teluk Bumbang, namun kisaran salinitas di kedua lokasi tersebut masih tergolong mendukung bagi kehidupan karang. Nybakken (1992) menyatakan bahwa karang merupakan organisme lautan sejati yang hidup pada habitat dengan salinitas air laut yang normal, yaitu antara $32-35 \%$.

Nitrat dan fosfat merupakan hara yang diperlukan oleh alga dalam pertumbuhannya. Kandungan hara berupa nitrat dan fosfat relatif tinggi di Teluk Awang (Tabel 3). Tutupan alga yang relatif tinggi di Teluk Awang menunjukkan hubungan yang positif atau seiring dengan relatif tingginya kandungan hara perairan Teluk Awang dibandingkan dengan Teluk Bumbang. Keberadaan alga merupakan indikator adanya perkembangan benthic life form pada terumbu buatan di Teluk Awang. Sementara keberadaan alga di Teluk Bumbang relatif sedikit, walaupun persentase karang hidup di kedua tempat tersebut masih belum muncul. Persentase karang hidup selain sebagai indikator kesehatan karang, juga berdampak positif terhadap kekayaan dan keanekaragaman ikan karang (Bell \& Gatzin, 1984). Di samping karang hidup, komponen lainnya seperti biota (yang meliputi alga dan biota lainnya) serta abiotik saling berinteraksi satu dengan yang lainnya dalam bentuk hubungan langsung (terkait perlindungan bagi juvenil) dan tidak langsung (terkait pembentukan struktur karang dan hidrologi di sekitarnya) serta interaksi terkait makanan (hubungan antara karang dengan ikan dan biota lainnya) (Choat \& Bellwood, 1991).

\section{Kesimpulan}

Sebanyak 8 - 16 spesies ikan karang dari 15 famili dijumpai pada terumbu buatan di Teluk Awang dan di Teluk Bumbang. Kelimpahan jenis ikan karang tertinggi (jumlah jenis tinggi namun dalam jumlah individu per jenis yang rendah) terjadi di Teluk Bumbang, yang diikuti oleh indeks keanekaragaman yang tergolong sedang, serta jumlah ikan mayor, target dan indikator yang relatif tinggi. Sebaliknya, kelimpahan individu ikan karang yang tinggi namun jumlah jenis sedikit lebih rendah dijumpai di Teluk Awang, dengan indeks ekologi yang tergolong rendah hingga sedang. Preferensi habitat ikan di Teluk Awang didukung oleh keberadaan alga dan biota lainnya, unsur hara dan salinitas, sementara di Teluk Bumbang didukung oleh kelimpahan fitozooplankton, DO, dan turbiditas. Tutupan alga, biota lain serta komponen abiotik diperkirakan masih akan terus mengalami fluktuasi yang menandakan perkembangan dan pertumbuhan terumbu yang masih berlangsung. Melihat adanya perkembangan tersebut dapat dikatakan bahwa penempatan terumbu buatan membawa dampak positif terhadap perlindungan habitat dan biota air di sekitarnya, sehingga diperlukan kajian lanjutan untuk memonitor kembali perubahan-perubahan yang terjadi baik pada biota maupun habitat di kedua teluk ini.

\section{Saran}

Perlu dilakukan monitoring secara kontinyu selama lima tahun setelah ditempatkannya terumbu buatan. Pengamatan kontinyu tidak hanya pada struktur komunitas ikan karang dan bentuk hidup organisme bentik namun juga pada kondisi lingkungan di sekitar lokasi, agar dapat diketahui bentuk interaksi antarterumbu karang dengan lingkungannya.

\section{Persantunan}

Tulisan ini merupakan kontribusi dari kegiatan penelitian "Pematangan Teknologi Rehabilitasi Habitat Lobster dengan Terumbu Buatan di Lombok Tengah”, tahun anggaran 2015 di Pusat Penelitian dan Pengembangan Perikanan. Keseluruhan penulis dalam paper ini merupakan kontributor utama.

\section{Daftar Pustaka}

Bailey-Brock, J. H. (2003). Coral reef polychaetes of Guam and Saipan, Mariana Islands. Micronesica, 35-36, 200-2017.

Bell, J. D. \& GaIzin, R. (1984). Influence of live coral cover on a coral reef fisheries communities. Mar. Ed. Prog. Ser., 15, $265-$ 274. 
Carr, M. H. \& Hixon, M.A. (1997). Artificial reefs: the importance of comparisons with natural reefs. Fisheries: special issue on artificial reef management, 22 (4), 28-33.

Choat, J. H. \& Bellwood, D. R. (1991). Reef Fishes: Their history and evolution. In: The Ecology of Fishes on Coral Reef (pp. 3466). California, United States: Academic Press.

Christy, L. (1991). Articial reef and fish aggregating device: Legal issues. Symposium on Artificial Reefs and Fish Aggregating Device as tools for The Management and Enhancement of Marine Fishery Resources. Colombo, Srilanka: 105-115.

Cinner, J.E., McClanahan, T.R., Graham, N.A.J., Daw, T.M., Maina, J., Stead, S.M., Wamukota, A., Brown, K. \& Bodin, O. (2012). Vulnerability of coastal communities to key impacts of climate change on coral reef fisheries. Glob. Environ. Chang., 22, 12-20.

Dartnall, A.J. \& Jones, M. (1986). A Manual of survey methods; living resources in coastal areas. ASEAN-Australia Cooperative Program on Marine Science Handbook. Australian Institute of Marine Science, Townsville

Dee, A. J. \& Parrish, J.D. (1994). Reproduction and trophic ecology of the soldier fish Myripristis amaena in tropical fisheries. Fishery Bulletin, 92, 516-530.

De Silva, M.W.R.N. (1989). Artificial reef: a practical means to enhance living marine resources. In: T. E. Chua,. \& D. Pauly (eds). Coastal area management in Southeast Asia: policies, management, strategies and case studies (pp. 173-180). ICLARM Conference Proceedings, 19, 254.

Dhahiyat, Y., Sinuhaji, D. \& Hamdani, H. (2003). Struktur komunitas ikan karang di daerah transplantasi karang Pulau Pari, Kepulauan Seribu. Jurnal Iktiologi Indonesia, 3 (2), 87-94.

English, S.E., Wilkinson, C. \& Baker, V. 1997. Survey Manual for Tropical Marine Resources. Australian Institute of Marine Science, Townsville, Australia.

Faizah, R., Sumiono, B., Sadiyah, L., Natsir, M., Anggawangsa, R. F. \& Hargiyatno, I. T. (2015). Pematangan teknologi rehabilitasi habitat lobster dengan terumbu buatan di Lombok Tengah. Laporan akhir penelitian. Pusat Riset Perikanan.

Fricke, H.W. (1977). Community structure, social organization and ecological requirements of coral reef fish (Pomacentridae). Helgolander wiss. Meeresunters, 30, 412 426.

Giyanto, Abrar, M., Hadi, T.A., Budiyanto, A., Hafizt, M., Salatalohy, A. \& Iswari, M.Y. (2017). Status terumbu karang Indonesia. Puslit Oseanografi - LIPI.

Hallock, P. (2009). Evolution and function of coral reef ecosystems. In: Valvak Cilek (ed.), Earth System: History and Natural Variability, 4, 434.

Hartati, S.T. (2008). Rehabilitasi wilayah pesisir melalui pengembangan terumbu buatan. $B A W A L, 2$ (1), 35-43.

Hobson, E.S. (1991). Trophic relationships of fishes specialized to feed on zooplankters above coral reefs. In: P.F. Sale (ed), The Ecology of Fishes on Coral Reefs (pp. 6995). San Diego, CA: Academic Press.

Hutomo, M. (1991). Teknologi terumbu buatan: suatu upaya untuk meningkatkan sumberdaya hayati laut. Oseana, 16 (1), 23 -33 .

Kepmen LH. (2001). Kriteria baku kerusakan terumbu karang. Keputusan Menteri Negara Lingkungan Hidup.

Kuiter, R.H. (1992). Tropical Reef-fishes of The Western Pacific, Indonesia and Adajacent Waters. Jakarta: PT. Gramedia Pustaka Utama.

Kusnanto. (2015). Struktur komunitas ikan pada ekosistem terumbu buatan di perairan pulau karya dan pulau harapan, Kabupaten Administrasi Kepulauan Seribu, DKI Jakarta. Skripsi pada Departemen Manajemen Sumber Daya Perairan. Institut Pertanian Bogor..

Lauwoie, I. (2010). Keterkaitan kondisi terumbu karang dengan kelimpahan ikan herbivora di pesisir selatan Teluk Kupang, Provinsi Nusa Tenggara Timur. Tesis pada Program Studi Pengelolaan Sumberdaya Pesisir dan Lautan. Institut Pertanian Bogor.

Ludwig, J. A. \& Reynolds, J.F. (1988). Statistical Ecology: A Primer on Methods and Computing. New York : John Wiley \& Sons.

Mujiyanto \& Sugianti, Y. (2014). Pengamatan komunitas ikan karang sebagai indikator keberhasilan pemasangan modul terumbu karang buatan di Perairan Teluk Saleh, Nusa Tenggara Barat. Prosiding Forum Nasional Sumberdaya Ikan I, 229-239.

Munday, P.L., Jones, G.P., Pratchett, M.S. \& Williams, A.J. (2008). Climate change and the future for coral reef fishes. Fish Fish, 9, 261-285. 
Nybakken, J. W. (1992). Biologi Laut Suatu Pendekatan Biologis. Jakarta : PT Gramedia.

Odum, E. P. (1971). Fundamental of Ecology. $3^{\text {rd }}$ edition. Toppan Company, Ltd.

Pardede, F.M. (2012). Efektivitas terumbu buatan berbahan dasar tempurung kelapa sebagai fish aggregating device di Pulau Pramuka Kepulauan Seribu. Skripsi pada Program Studi Teknologi dan Manajemen Perikanan Tangkap. Institut Pertanian Bogor.

Romimoharto, K. \& Juwana, S. (2001). Biologi Laut: Ilmu Pengetahuan tentang Biota Laut. Jakarta: Djambatan.

Satria, H. \& Mujiyanto. (2011). Struktur komunitas ikan karang di lokasi terumbu karang buatan di Perairan Teluk saleh, Nusa Tenggara Barat (p. 16). Prosiding Forum Nasional Pemacuan Sumber Daya Ikan III.

Seaman, W.J. (2000). Artificial reef evaluation with application natural marine habitats. Washington DC, USA: CRC press LLC.

Sentosa, A.A. \& Satria, H. (2011). Relung ekologi beberapa ikan target hasil tangkapan bubu di sekitar terumbu buatan Perairan Teluk Saleh, Nusa Tenggara Barat. J. Lit. Perikan. Ind., 17 (3), 209-219.

Sumiono, B., Hartati, S.T., Oktaviani, D., Prianto, Y., Sulaiman, P.S., Hargiyatno, I. T. \&
Anggawangsa, R. F. (2014). Model pengelolaan habitat melalui terumbu karang buatan dalam upaya pemulihan stok udang karang/lobster di perairan Lombok. Laporan akhir penelitian. Pusat Riset Perikanan.

Supriharyono. (2000). Pengelolaan Ekosistem Terumbu Karang. Jakarta: Djambatan. Takada, Y. (2012). Variations in cryptic assemblages in coral-rubble interstices at a reef slope in Ishigaki Island, Japan. Fisheries Science, 78 (1), 91-98.

Tarigan, S.A.R., Dwindaru, B. \& Hardyanti, F. (2009). Kondisi ikan karang di Pulau Pramuka Kepulauan Seribu, Jakarta. Jurnal Penelitian Sains, 13 (3), 31-36.

Yanuar, A. \& Aunurohim. (2015). Komunitas ikan karang pada tiga model terumbu buatan (artificial reef) di Perairan Pasir Putih Situbondo, Jawa Timur. Jurnal Sains dan Seni, 4 (1), 2337-3520.

Yunaldi, Arthana, I.W.\& Astarini, I.A. (2011). Studi perkembangan struktur komunitas ikan karang di terumbu buatan berbentuk hexadome pada berbagai kondisi perairan di Kabupaten Buleleng, Bali. Ecotrophic, 6 (2),

107-112. 